International

Medical Society

http://imedicalsociety.org

\title{
The Role of Chlamydia Trachomatis in the Pathogenesis of Female Reproductive Organs Cancers
}

Louis Chukwuemeka Ajonuma1, Kehinde Segun Nathaniel ${ }^{1}$, Adebisi Saka Bamiro ${ }^{1}$, Samira Lobo Makanjuola ${ }^{2}$

\section{Abstract}

Chlamydia trachomatis (C. trachomatis) is an intracellular obligate bacterium. It is the most common cause of pelvic inflammatory disease (PID) amongst a spectrum of diseases. Chlamydia infection is of a major public health concern especially in developing countries. It is estimated that about 600 million people are infected worldwide annually yet its roles in the pathogenesis of gynecological cancers are poorly understood and has not been fully elucidated. An understanding of the mechanisms underlying cancer development following PID due to C. trachomatis will be essential in prevention and providing more rational treatments. This review discusses the mechanisms and sequence of events linking Chlamydial infections to carcinogenesis in the female reproductive organs. Possible links between C. trachomatis infection and cancer development in the female reproductive organs are proposed. C. trachomatis infection as a co factor is also re-examined in light of these possible mechanisms.

\section{Introduction}

Chlamydia trachomatis (C. trachomatis) is an intracellular obligate gram-negative bacterium. It exists in two forms, alternating between elementary body (EB) that is metabolically inactive but highly infectious and reticulate body that is metabolically active and involved in its replication. C. trachomatis depends on its host for energy, metabolism and reproduction (as reviewed by Ajonuma et al.) [1]. Chlamydia infection is of a major public health concern and it is estimated that about 600 million people are infected worldwide annually [2]. C. trachomatis infect epithelia of many organs leading to a spectrum of pathological
1 Department of Physiology, Lagos State University College of Medicine, Ikeja, Lagos, Nigeria.

2 Department of Pharmacology, Lagos State University College of Medicine, Ikeja, Lagos, Nigeria.

\section{Contact information:}

Louis C. Ajonuma.

Address: Department of Physiology, Medical Research Complex, Lagos State University College of Medicine (LASUCOM), \# 1-5 Oba Akinjobi Way, Ikeja, Lagos, Nigeria.

झ Louis.ajonuma@lasucom.edu.ng

\section{Keywords}

Chlamydia Trachomatis, Female Reproductive Organs, Infection, Cancers. 
conditions such as cervicitis, endometritis, salpingitis epidydimitis, prostatitis, lymphangitis, pneumonitis, conjunctivitis, keratitis and trachoma the main cause of preventable blindness [1]. Different serovars do have tropisms for different epithelia and tissues. Serovars $A$ to $C$ infects the eye, while serovars $D$ to $K$ the genitourinary tract [3]. Majority of the cases are sub-acute leading to persistence and /or chronic infection, which elicits immune response, tissue scaring, damage and other cascade of events such as epithelial transformation.

However, there is little information in the literature regarding the mechanisms of $C$. trachomatis infection in the pathogenesis of gynecological cancers. This review proposes the possible links between $C$. trachomatis in pelvic inflammatory disease and the subsequent gynecological cancers. The roles of $C$. trachomatis as a cofactor in the pathogenesis of gynecological cancers are examined in light of these mechanisms. New research on elucidating the involvement of $C$. trachomatis in gynecological cancers is suggested.

\section{Results}

\section{Chlamydial infection of the Pelvic organs}

C. trachomatis infection is the most common sexually transmitted bacterial infection worldwide [4] and the leading cause of pelvic inflammatory disease (PID) $[5,6]$. There is evidence that about $20 \%$ of women with chlamydial lower genital tract infection develop PID [7] while Jones et al. reported that 41\% of women with $C$. trachomatis infection had endometrial infections [8]. Endometritis due to C. trachomatis has also been reported [9-12]. C. trachomatis was recovered from uteri and Fallopian tubes of women with acute salpingitis [11] and its DNA detected in women with post-infectious infertility $[13,14]$. Serological studies on women who had salpingitis demonstrated strong association of tubal factor related infertility with previous $C$. trachomatis infection [8]. There is increased prevalence of spontaneous abortion in women who had chlamydial salpingitis [15] or had been previously exposed to C. trachomatis [16]. Interestingly, most C. trachomatis infections are sub-acute, leading to persistent and / or chronic infections, eliciting immune response.

Heat shock proteins (HSP) are increased in women with previous chlamydial infections [17]. Persistent infection through constant exposure to C. trachomatis leads to production of HSP that elicits intense immune and inflammatory reactions, leading to tissue scarring and endometrial and Fallopian tube damage. HSP 10 is associated with tubal factor infertility in a C. trachomatis exposed population [18] and HSP 57 with elementary and reticulate bodies showed delayed hypersensitivity response [17]. HSP 60 is capable of eliciting intense mononuclear inflammation and elaboration of inflammatory cytokines $[14,19]$. Chlamydial HSP may function in at least two different ways to promote chronic disease. Firstly, through direct antigenic stimulation and secondly as signal transducers that result in macrophage activation [19].

Despite $C$. trachomatis being recognized for long as the most important cause of chronic PID worldwide, the sequence of events linking Chlamydial infections to carcinogenesis in the female reproductive organs has not been elucidated to a satisfactory extent.

\section{Pathogenesis of Chlamydial infections in carcinogenesis}

Chronic and or persistent bacterial infections have been implicated in the occurrence of cancer [20]. Several studies have associated chlamydial infection with the development of cervical [21, 22] and ovarian [23] carcinoma.

Chlamydia can establish asymptomatic, persistent infections by several mechanisms, including antibiotic resistance, immune evasion, and apoptosis suppression [24]. C. trachomatis triggers activation of oncogenic Ras-Raf-MEK-ERK pathway components 
$[25,26]$ and production of reactive oxygen species (ROS) to support its growth [27].

It has been reported in various human and other mammalian cell lines that Chlamydia infection can lead to significant increases in host cell multinucleation [28], a condition well linked to tumorigenesis $[29,30]$.

Bacterial pathogens are known to modify the chromatin architecture of host cells, thus manipulating host transcriptomes, such as to suppress immune responses [31]. C. pneumoniae induces modifications of histones $\mathrm{H} 3$ and $\mathrm{H} 4$, which plays an important role in cytokine production [32]. Recently, it has been reported that chlamydial nuclear effector protein (Nue) has histone methyltransferase activity that targets histones $\mathrm{H} 2 \mathrm{~B}, \mathrm{H} 3$, and $\mathrm{H} 4$ [33]. Chromatin alterations, such as histone modifications, may induce somatically heritable changes of gene activity and thus have oncogenic potential [34]. Collectively, these data establish that bacterial pathogens induce multiple types of histone PTMs, although the mechanisms and extent of this phenomenon requires elucidation.

Chlamydia trachomatis infection causes mitotic spindle pole defects [35] and resists apoptosis induction in actively dividing cells $[36,37]$ leading to cell transformation and carcinogenesis.

Chlamydia infection has been reported to increase supernumerary centrosomes, abnormal spindle poles, and chromosomal segregation defects [38], centrosome amplification and multipolar spindle formation that may lead to chromosomal instability. Inappropriate activation of ERK and elevated global heterochromatin is a hallmark of many cancers [39, 40].

It has been reported that Chlamydial infection alters the transcription of host cell genes including those for cell differentiation, transcription factors and inhibition of apoptosis [41]. It has also been demonstrated that $C$. trachomatis infection results in increased tyrosine phosphorylation of several host proteins including those involved in signal transduc- tion pathways [41, 42, 43, 44]. During Chlamydial infection, bacteria binding may stimulate receptor signaling leading to protein tyrosine phosphorylation.

Recently, the role of chromatin and histone modifications in promoting DNA damage responses (DDRs) and genome stability have gained prominence [45]. Upon detection of DNA double-strand breaks (DSBs), cells activate DDR pathways that detect DNA lesions and signal their presence by mediating responses such as cell-cycle arrest, DNA repair, and, under some circumstances, apoptosis. Phosphorylation of H2AX Ser139 $({ } \mathrm{H} 2 \mathrm{AX})$ is a prominent chromatin modification in response to DSBs that acts as a signal for recruitment of repair proteins including PATM and 53BP1 to DNA break sites. Deficiencies in DNA damage signaling and repair pathways lead to genetic instability, which in turn might enhance oncogenesis [46].

Deficiencies in DNA damage signaling and repair pathways lead to genetic instability, which in turn might enhance oncogenesis [46]. Chromatin alterations, such as histone modifications, may induce somatically heritable changes of gene activity and thus have oncogenic potential [34]. Histone posttranslational modifications (PTMs) are typically induced by signal transduction pathways activated in response to cellular stimuli. One prominent pathway implicated in histone PTMs is the mitogen-activated protein kinase (MAPK) cascade, which leads to histone H3 serine 10 (H3S10) phosphorylation in a promoter-specific manner, targeting only a subset of genes [47]. Bacterial pathogens such as Mycobacteria, Shigella, Listeria, and Helicobacter are known to modify the chromatin architecture of host cells, thus manipulating host transcriptomes, e.g., to suppress immune responses [31]. Furthermore, C. pneumoniae induces modifications of histones $\mathrm{H} 3$ and $\mathrm{H} 4$, which play an important role in cytokine production [32]. More recently, the chlamydial nuclear effector protein (Nue) was shown to have histone methyltransfera- 
se activity that targets histones $\mathrm{H} 2 \mathrm{~B}, \mathrm{H} 3$, and $\mathrm{H} 4$ [33]. Collectively, these data establish that bacterial pathogens induce multiple types of histone PTMs, although the mechanisms and extent of this phenomenon requires elucidation.

Furthermore, Chlamydia infection has been shown to increase supernumerary centrosomes, abnormal spindle poles, and chromosomal segregation defects [38]. Inappropriate activation of ERK and elevated global heterochromatin is a hallmark of many cancers [39,40].

Chlamydiae produce a unique family of T3SS effectors termed inclusion membrane proteins (Incs) [48, 49]. These effectors are translocated across, and inserted into, the inclusion membrane, in which they are ideally positioned to mediate host-pathogen interactions [50]. They have hydrophobic domains composed of two closely spaced membrane-spanning regions that are separated by a short hairpin loop, with their amino terminus and/or carboxyl terminus predicted to extend into the cytoplasm of the host cell [51]. Incs are primarily expressed early during infection, when they may be important in the establishment of the inclusion, and at mid-cycle, when they may be involved in the maintenance of the inclusion and the acquisition of nutrients [50]. Genome-wide comparisons reveal a core set of Incs that are shared across Chlamydia spp. as well as diverse species-specific Incs that may be key determinants of host tropism and site-specific disease [48, 49]. Incs share little homology to each other or to other known proteins, with the exception of coiled-coil or soluble $\mathrm{N}$-ethylmaleimide-sensitive factor attachment protein receptor (SNARE)-like domains, which provides limited insight into their functions [51]. Incs are hypothesized to recruit host proteins to the inclusion membrane to promote fusion with nutrient-rich compartments, inhibit fusion with degradative compartments, hijack host machinery or organelles, disrupt normal host pathways, or as- semble novel complexes with new functions [50]. The Inc-host interactions identified thus far indicate that Incs participate in numerous processes, including the rearrangement of the host cell cytoskeleton, membrane dynamics, centrosome tethering, lipid acquisition and resistance to apoptosis [50]. In addition, Incs form homotypic or heterotypic complexes on the surface of the inclusion $[52,53]$. Finally, Incs may provide structural stability to the growing inclusion membrane [54]. A large-scale proteomic screen of Incs in C. trachomatis has revealed putative host binding partners for approximately two-thirds of Incs [55]. All these complex formations and cytoskeleton rearrangements may lead to host cell tissue transformation. C. trachomatis infection also shown to upregulate the expression of cystic fibrosis transmembrane regulator (CFTR) gene in reproductive organs [56] and in hydrosalpinx [57] induced epithelial transformation to pseudostratification and focally attenuated epithelium. These epithelial transformations may irreversibly progress to cancer. Figure 1 shows the proposed sequence of events linking $C$. trachomatis infection to increased chromosomal instability and then gynecological cancers.

\section{C. trachomatis as a co-factor in carncinogenesis}

Although human papilloma virus (HPV) is known to cause cervical cancer, there is some evidence that C. trachomatis may also act as a co-factor [58]. Chlamydial infections have been epidemiologically linked to cervical cancer in women co-infected with the HPV [59] and when several studies from different countries were pooled 60]. Studies have also shown that $C$. trachomatis infection confers an increased risk of squamous cell carcinoma, after adjusting for HPV infection, smoking, and depending on the serotype involved [61-65]. Some C. trachomatis serotypes $\mathrm{B}, \mathrm{D}, \mathrm{E}, \mathrm{G}, \mathrm{I}$, and J have been found to increase the risk of squamous cell cancer $[66,67]$, while serotypes $C, F, H$, and $K$ 
Figure 1.

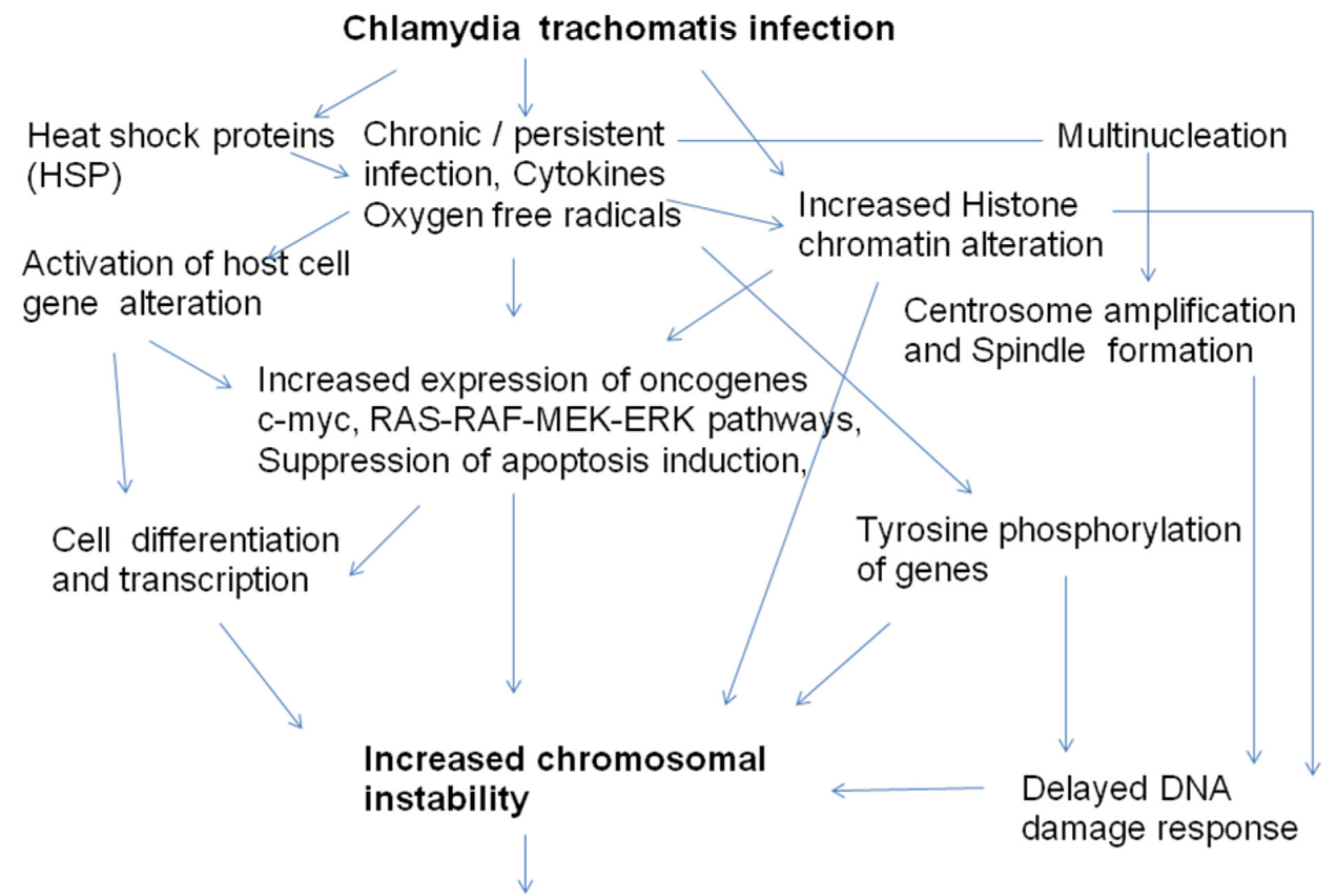

\section{Cancer formation}

A schematic illustration of proposed mechanisms and sequence of events linking C. trachomatis infection and cancer development in the female reproductive organs. C. trachomatis infection results in the production of Heat Shock Proteins (HSP), histone chromatin alterations and chronic and or persistent infection. This leads to increased expression of oncogens and suppression of apoptosis induction. As well as tyrosine phosphorylation of genes, centrosome amplification, spindle formation and delayed DNA damage response. All these lead to increased chromosomal instability, cell differentiation and cancer formation.

have not. How C. trachomatis exactly enhance oncogenesis as a co factor to HPV infection is not fully understood but it has been suggested to be due to chronic inflammation and metaplasia [68]. Other mechanisms have also been proposed. C. trachomatis may promote the persistence of HPV infection $[69,70]$. HPV can remain latent for years after infection. In the presence of $C$. trachomatis, HPV high risk oncogens E6 and E7 may undergo activation leading to chromosomal abnormalities and immortalization.

In vitro infection of fibroblasts and cervical tissue that were free of HPV showed decreased expression of the tumor suppressor gene caveolin-1 and increased expression of the proto-oncogene c-myc, indicating there may be other possible ways that $C$. trachomatis may promote oncogenesis [71]. Since C. trachomatis infection can induce centrosome abnormalities, spindle effects, and chromosome segregation errors leading to cell transformation, the presence of these defects within infected actively dividing cells is a possible mechanism for $C$. trachomatis as a co factor in cancer formation. Figure $\mathbf{2}$ shows the proposed possible sequence of events linking $C$. trachomatis infection to increased chromosomal instability, epithelial cell differentiation and immortalization in the presence of HPV. 
Figure 2.
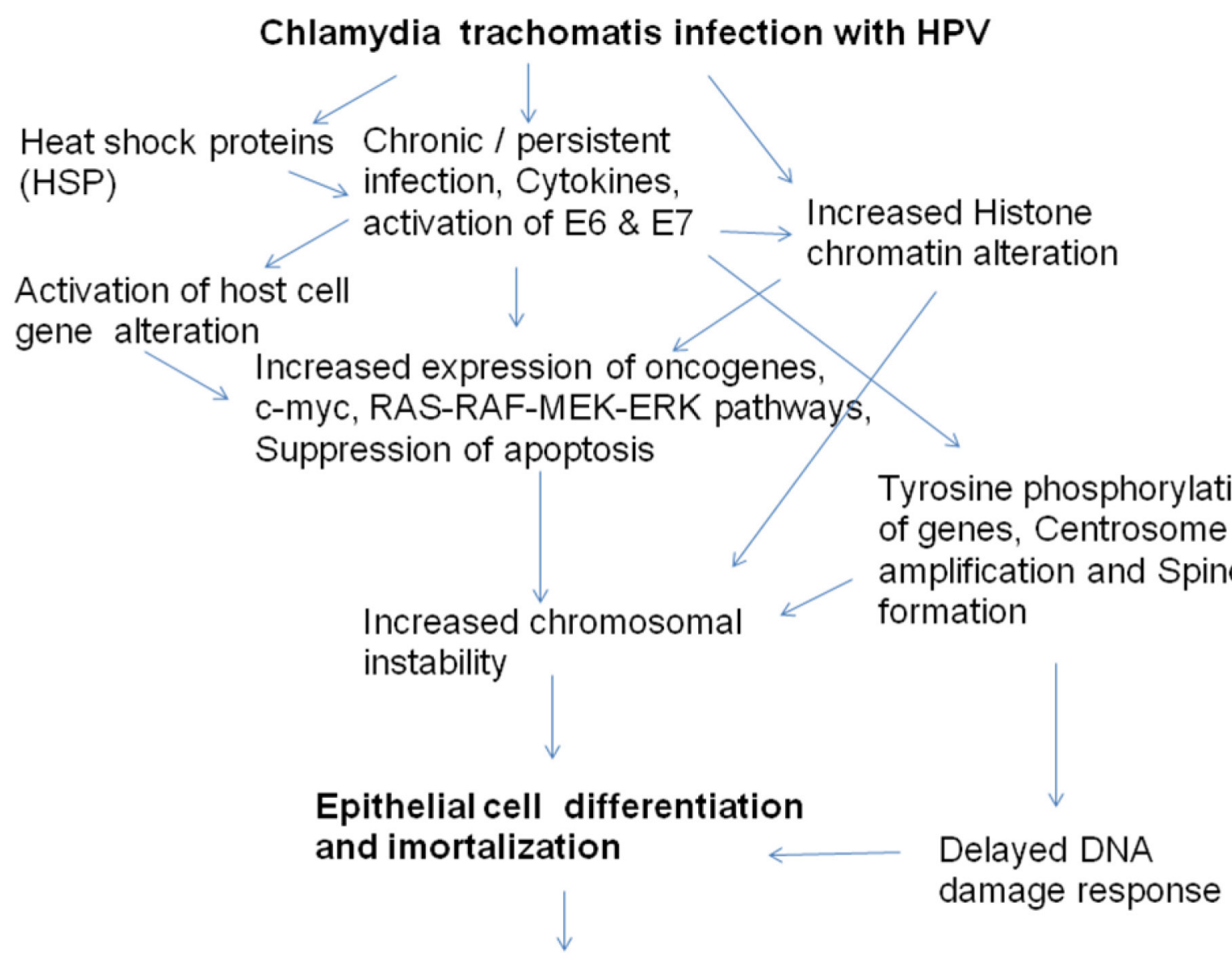

\section{Cancer formation}

A schematic illustration of proposed mechanisms and sequence of events linking C. trachomatis infection and cancer development in the female reproductive organs. C. trachomatis infection results in the production of Heat Shock Proteins (HSP), histone chromatin alterations and chronic and or persistent infection. This leads to increased expression of oncogens and suppression of apoptosis induction. As well as tyrosine phosphorylation of genes, centrosome amplification, spindle formation and delayed DNA damage response. All these lead to increased chromosomal instability, cell differentiation and cancer formation.

\section{Conclusions}

In summary, chronic and persistent inflammation of the female reproductive organs epithelia following chlamydial infections leads to subsequent tissue transformation, causes mitotic spindle pole defects, alters the transcription of host cell genes, decreased expression of the tumor suppressor genes, increased tyrosine phosphorylation of several host proteins including those involved in signal transduction pathways, increased expression of the proto-oncogens like c-myc, leading to delayed DNA damage response and chromosomal instability then promoting oncogenesis. New research focusing on the above mentioned pathways may provide crucial information for a better understanding on the role of C. trachomatis infection in pathogenesis of gynecological cancers.

\section{Funding}

This project is funded by Institution Research Base grant to Louis C. Ajonuma from Tertiary Education Trust Fund (TETfund) Nigeria. 


\section{References}

1. Ajonuma LC, Ng EHY, Chan HC New insights into the mechanisms underlying hydrosalpinx fluid formation and its adverse effect on IVF outcome. Hum. Reprod. Update, 2002 8,255-64.

2. Geneva: World Health Organization; Global prevalence and incidence of selected curable sexually transmitted diseases: Overview and estimates. 2011

3. Abdelsamed Hossam, Peters Jan, and Byrne Gerald I Genetic variation in Chlamydia trachomatis and their hosts: impact on disease severity and tissue tropism. Future Microbiol. 2013 Sep; 8(9): 1129-1146.

4. Paavonen, J. and Eggert-Kruse, W. Chlamydia trachomatis: impact on human reproduction. Human Reprod Update, 1999 5, 433-47.

5. Walters, M.D., Eddy, C.A., Gibbs, R.S., Schachter, J., Holden, A.E.C. and Pauerstein, C.J. Antibodies to Chlamydia trachomatis and risk for tubal pregnancy. Am. J. Obstet. Gynecol., 1988 159, 942-946.

6. Cates, W. and Wasserheit, J.N. Genital chlamydial infections: epidemiology and reproductive sequelae. Am. J. Obstet. Gynecol., 1991 164, 1771-1781.

7. Paavonen, J. and Eggert-Kruse, W. Chlamydia trachomatis: impact on human reproduction. Hum. Reprod. Update, 1999 5, 433-447.

8. Jones, R.B., Mammel, J.B., Shepard, M.K. and Fisher, R.R. Recovery of Chlamydia trachomatis from the endometrium of women at risk for chlamydial infection. Am. J. Obstet Gynecol., 1986 155, 35-39.

9. Gump, D.W., Dickstein, S. and Gibson, M. Endometritis related to Chlamydia trachomatis infection. Ann. Intern. Med., 1981 95, 61.

10. Mardh, P.A., Moller, B.R. and Paavonen, J. Chlamydial infection of the female genital tract with emphasis on pelvic in־ammatory disease. A review of Scandinavian studies. Sex. Transm. Dis., $1981,8,140$

11. Wolner-Hanssen, P., Mardh, P.A., Moller, B. and Westrom, L. Endometrial infection in women with chlamydial salpingitis. Sex. Transm. Dis., 1982 9, 84.

12. Winkler, B., Gallo, L., Reumann, W., Richart, R.M., Mitao, M. and Crum, C.P. Chlamydial endometritis: a histological and immunohistochemical analysis. Am. J. Surg. Pathol., 1984 8, 771.

13. Patton DL, Askienazy-Elbhar M, Henry-Suchet J, Campbell LA, Cappuccio A, Tannous W, Wang SP, Kuo CC. Detection of Chlamydia trachomatis in fallopian tube tissue in women with postinfectious tubal infertility. Am. J. Obstet. Gynecol., 1994, $171,95-101$
14. Witkin, S.S. (1999) Immunity to heat shock proteins and pregnancy outcome. Infect. Dis. Obstet. Gynecol., 7, 35-38.

15. Toth, M., Jeremias, J., Ledger, W.J. and Witkins, S.S. In vivo tumour necrosis factor reproduction in women with salpingitis. Surg. Gynecol. Obstet., 1992, 174, 359-362.

16. Licciardi, F., Grifo, J.A., Rosenwaks, Z. and Witkin, S. Relation between antibodies to Chlamydia trachomatis and spontaneous abortion following in vitro fertilization. J. Assist. Reprod. Genet. 1992, 9, 207-209.

17. Witkin, S.S., Sultan, K.M., Neal, G.S., Jeremias, J. Grifo, J.A. and Rosenwaks, Z. Unsuspected Chlamydia trachomatis infection and in vitro fertilization outcome. Am. J. Obstet. Gynecol., 1994, 171, 208-214.

18. La Verda, D., Albanese, L.N., Ruther, P.E., Morrison, S.G., Morrison, R.P., Ault, K.A. and Bryne, G.I. Seroreactivity to Chlamydia trachomatis Hsp10 correlates with severity of human genital tract disease. Infect. Immun., 2000, 68, 303-309.

19. La Verda, D., Kalayoglu, M.V. and Bryne, G.I Chlamydial heat shock proteins and disease pathology: new paradigms for old problems? Infect. Dis. Obstet. Gynecol., 1999, 7, 64-71.

20. Vogelmann R, M.R. Amieva. The role of bacterial pathogens in cancer Curr. Opin. Microbiol., 2007, 10, pp. 76-81.

21. Arnheim Dahlström, K. Andersson, T. Luostarinen, S. Thoresen, H. Ögmundsdottír, L. Tryggvadottír, F. Wiklund, G.B. Skare, C. Eklund, K. Sjölin, et al. B Prospective seroepidemiologic study of human papillomavirus and other risk factors in cervical cancer Cancer Epidemiol. Biomarkers Prev., 20 2011, pp. 2541-2550.

22. Koskela, P., T. Anttila, T. Bjorge, A. Brunsvig, J. Dillner, M. Hakama, T. Hakulinen, E. Jellum, M. Lehtinen, P. Lenner, T. Luostarinen, E. Pukkala, P. Saikku, S. Thoresen, L. Youngman, and J. Paavonen. Chlamydia trachomatis infection as a risk factor for invasive cervical cancer. Int. J. Cancer 2000, 85:35-39.

23. Shanmughapriya S, G. Senthilkumar, K. Vinodhini, B.C. Das, N. Vasanthi, K. Natarajaseenivasan. Viral and bacterial aetiologies of epithelial ovarian cancer Eur. J. Clin. Microbiol. Infect. Dis., 2012, 31, 2311-2317.

24. Mpiga $P$, Ravaoarinoro $M$. Chlamydia trachomatis persistence: an update. Microbiol Res. 2006, 161(1):9-19.

25. Gurumurthy R K, Mäurer A P., Machuy N, Hess S, Pleissner K P., Schuchhardt J, Rudel T and Meyer T F. A Loss-of-Function Screen Reveals Ras- and Raf-Independent MEK-ERK Signaling During Chlamydia trachomatis Infection. Science Signaling 2010, 3 (113), ra21.

26. Vignola M J., Kashatus D F., Taylor G A., Counter C M., and Valdivia R H. cPLA2 Regulates the Expression of Type I Interferons and Intracellular Immunity to Chlamydia trachomatis. J Biol Chem. 2010 285(28): 21625-21635.

27. Abdul-Sater, N. Saïd-Sadier, V.M. Lam, B. Singh, M.A. Pettengill, F. Soares, I. Tattoli, S. Lipinski, S.E. Girardin, P. Rosenstiel, D.M. Ojcius. Enhancement of reactive oxygen species production and chlamydial infection by the mitochondrial Nod-like family member NLRX1 J. Biol. Chem., (2010) 285, 41637-41645. 
28. Greene W., Zhong G. Inhibition of host cell cytokinesis by Chlamydia trachomatis infection. J. Infect. 2003, 47:45-51.

29. Fujiwara T., et al. Cytokinesis failure generating tetraploids promotes tumorigenesis in p53-null cells. Nature 2005, 437:1043-1047.

30. Ganem N. J., Storchova Z., Pellman D. Tetraploidy, aneuploidy, and cancer. Curr. Opin. Genet. Dev. 2007, 17:157-162

31. Hamon and Cossart, M.A. Hamon, P. Cossart .Histone modifications and chromatin remodeling during bacterial infections Cell Host Microbe, 2008, 4, 100-109.

32. Schmeck B, W. Beermann, P.D. N'Guessan, A.C. Hocke, B. Opitz, J. Eitel, Q.T. Dinh, M. Witzenrath, M. Krüll, N. Suttorp, S. Hippenstiel. Simvastatin reduces Chlamydophila pneumoniaemediated histone modifications and gene expression in cultured human endothelial cells .Circ. Res., 2008 102, 888-895.

33. Pennini M.E, S. Perrinet, A. Dautry-Varsat, A. Subtil .Histone methylation by NUE, a novel nuclear effector of the intracellular pathogen Chlamydia trachomatis PLoS Pathog., 6 (2010), p. e1000995.

34. Füllgrabe et al., 2011 J. Füllgrabe, E. Kavanagh, B. Joseph. Histone onco-modifications Oncogene, 30 2011, 3391-3403.

35. Knowlton Andrea E., Heather M. Brown, Theresa S. Richards, Lauren A. Andreolas, Rahul K. Patel, and Scott S. Grieshaber (2011) Chlamydia trachomatis infection causes mitotic spindle pole defects independently from its effects on centrosome amplification. Traffic. 2011 12(7): 854-866.

36. Fan, T., H. Lu, H. Hu, L. Shi, G. A. McClarty, D. M. Nance, A. H. Greenberg, and $\mathrm{G}$. Zhong. Inhibition of apoptosis in chlamydiainfected cells: blockade of mitochondrial cytochrome c release and caspase activation. J. Exp. Med. 1998, 187:487-496.

37. Greene W., Xiao Y., Huang Y., McClarty G., Zhong G. Chlamydiainfected cells continue to undergo mitosis and resist induction of apoptosis. Infect. Immun. 2004. 72, 451-460

38. Grieshaber S.S., Grieshaber N.A., Miller N., Hackstadt T. Chlamydia trachomatis causes centrosomal defects resulting in chromosomal segregation abnormalities Traffic, (2006), 7. 940949.

39. Di Micco R., Sulli G., Dobreva M, Liontos M., Botrugno O.A., Gargiulo G., G. dal Zuffo G., Matti V., d'Ario G., Montani E., et al. Interplay between oncogene-induced DNA damage response and heterochromatin in senescence and cancer Nat. Cell Biol., 13 (2011), pp. 292-302.

40. Roberts P.J. and Der, C.J. Targeting the Raf-MEK-ERK mitogenactivated protein kinase cascade for the treatment of cancer Oncogene, 26 (2007), 3291-3310.

41. Xia, M.S., Bumgarner, R.E., Lampe, M.F. and Stamm, W.E. chlamydia trachomatis infection alters host Cell transcription in diverse Cellular pathways. J Infect Dis (2003) 187, 424-434.

42. Bliska, J.B., Galan, J.E. and Falkow, S. Signal transduction in the mammalian cell during bacteria attachment and entry. Cell, 1993, 73, 903-920
43. Birkelund, S., Johnson, H. and Christiansen, G. Chlamydia trachomatis serovar L2 induces protein tyrosine phosphorylation during uptake by Hela cells. Infect. Immun., 1994, 62, 49004908.

44. Fawaz, F.S., Van Ooij, C. and Homola, E. Infection with Chlamydia trachomatis alters the tyrosine phosphorylation and/ or localization of several host cell protein including contacting. Infect. Immun., 1997, 5, 301-5308.

45. Miller K.M, Jackson S.P. Histone marks: repairing DNA breaks within the context of chromatin Biochem. Soc. Trans., 40 (2012), pp. 370-376.

46. O'Driscoll M, P.A. Jeggo. The role of double-strand break repairinsights from human genetics Nat. Rev. Genet., 7 (2006), pp. 45-54.

47. Clayton A.L., Mahadevan L.C., MAP kinase-mediated phosphoacetylation of histone $\mathrm{H} 3$ and inducible gene regulation FEBS Lett., (2003), 546 51-58.

48. Dehoux P, Flores R, Dauga C, Zhong G, Subtil A. Multi-genome identification and characterization of Chlamydiae-specific type III secretion substrates: the Inc proteins. BMC Genomics. 2011; 12:109.

49. Lutter El, Martens C, Hackstadt T. Evolution and conservation of predicted inclusion membrane proteins in Chlamydiae. Comp. Funct. Genomics. 2012; 2012:362104.

50. Moore ER, Ouellette SP. Reconceptualizing the chlamydial inclusion as a pathogen-specified parasitic organelle: an expanded role for Inc proteins. Front. Cell. Infect. Microbiol. 2014; 4:157.

51. Hackstadt T. In: Intracellular Pathogens 1: Chlamydiales. Tan M, Bavoil PM, editors. Vol. 1. ASM press; 2012. pp. 126-148.

52. Gauliard E, Ouellette SP, Rueden KJ, Ladant D. Characterization of interactions between inclusion membrane proteins from Chlamydia trachomatis. Front. Cell. Infect. Microbiol. 2015; 5:13.

53. Mital J, Miller NJ, Fischer ER, Hackstadt T. Specific chlamydial inclusion membrane proteins associate with active Src family kinases in microdomains that interact with the host microtubule network. Cell. Microbiol. 2010; 12:1235-1249.

54. Mital J, Miller NJ, Dorward DW, Dooley CA, Hackstadt T. Role for chlamydial inclusion membrane proteins in inclusion membrane structure and biogenesis. PLoS ONE. 2013; 8:e63426.

55. Mirrashidi KM, et al. Global mapping of the Inc-human interactome reveals that retromer restricts Chlamydia infection. Cell Host Microbe. 2015; 18:109-121.

56. Ajonuma LC, Chan PSK, Ng EHY, Fok KL, Wong CHY, Tsang LL, Tang XX, Ho LS, Lau MC, Chung CM, He Q, Huang HY, Yang DZ, Rowlands DK, Chung YW, Chan HC Involvement of Cystic fibrosis transmembrane conductance regulator (CFTR) in the pathogenesis of hydrosalpinx induced by Chlamydia trachomatis infection. J Obstet. Gynaecol. Res. (2008) 34,923-30. 
57. Ajonuma LC, Ng EHY, Tsang LL, Cheung ANY, Chow PH, Hung CY, Briton-Jones C, Lok IH, J Haines CJ, Chan HC Increased cystic fibrosis transmembrane conductance regulator (CFTR) expression in human hydrosalpinx. Hum. Reprod. 20, 1228-34.

58. Deluca GD, Basiletti J, Schelover E, Vásquez ND, Alonso JM, Marín HM, Lucero RH, Picconi MA.( 2011) Chlamydia trachomatis as a probable cofactor in human papillomavirus infection in aboriginal women from northeastern Argentina. Braz J Infect Dis. (2005) 15(6):567-72.

59. Knowlton A E., Fowler L J., Patel R K, Wallet S M., Grieshaber S S. Chlamydia induces Anchorage Indepence in 3T3 cells and Detrimental cytological Defects in an infection model. Plos one, (2013) 8(1): e54022.

60. Smith, J. S., C. Bosetti, N. Munoz, R. Herrero, F. X. Bosch, J. ElufNeto, C. J. Meijer, A. J. Van Den Brule, S. Franceschi, and R. W. Peeling. Chlamydia trachomatis and invasive cervical cancer: a pooled analysis of the IARC multicentric case-control study. Int. J. Cancer 2004, 111:431-439.

61. Di Felice, V., S. David, F. Cappello, F. Farina, and G. Zummo. Is chlamydial heat shock protein 60 a risk factor for oncogenesis? Cell. Mol. Life Sci. (2005). 62:4-9.

62. Hinkula, M., E. Pukkala, P. Kyyronen, P. Laukkanen, P. Koskela, J. Paavonen, M. Lehtinen, and A. Kauppila. A population-based study on the risk of cervical cancer and cervical intraepithelial neoplasia among grand multiparous women in Finland. Br. J. Cancer (2004). 90:1025-1029.

63. Naucler, P., H. C. Chen, K. Persson, S. L. You, C. Y. Hsieh, C. A. Sun, J. Dillner, and C. J. Chen. Seroprevalence of human papillomaviruses and Chlamydia trachomatis and cervical cancer risk: nested case-control study. J. Gen. Virol. 2007.88:814-822.

64. Paavonen, J., K. P. Karunakaran, Y. Noguchi, T. Anttila, A. Bloigu, J. Dillner, G. Hallmans, T. Hakulinen, E. Jellum, P. Koskela, M. Lehtinen, S. Thoresen, H. Lam, C. Shen, and R. C. Brunham. Serum antibody response to the heat shock protein 60 of Chlamydia trachomatis in women with developing cervical cancer. Am. J. Obstet. Gynecol. 2003.189:1287-1292.

65. Wallin, K. L., F. Wiklund, T. Luostarinen, T. Angstrom, T. Anttila, F. Bergman, G. Hallmans, I. Ikaheimo, P. Koskela, M. Lehtinen, U. Stendahl, J. Paavonen, and J. Dillner. A population-based prospective study of Chlamydia trachomatis infection and cervical carcinoma. Int. J. Cancer 2002. 101:371-374.

66. Anttila, T., P. Saikku, P. Koskela, A. Bloigu, J. Dillner, I. Ikaheimo, E. Jellum, M. Lehtinen, P. Lenner, T. Hakulinen, A. Narvanen, E. Pukkala, S. Thoresen, L. Youngman, and J. Paavonen. Serotypes of Chlamydia trachomatis and risk for development of cervical squamous cell carcinoma. JAMA 2001. 285:47-51.
67. Madeleine, M. M., T. Anttila, S. M. Schwartz, P. Saikku, M. Leinonen, J. J. Carter, M. Wurscher, L. G. Johnson, D. A. Galloway, and J. R. Daling. Risk of cervical cancer associated with Chlamydia trachomatis antibodies by histology, HPV type and HPV cofactors. Int. J. Cancer 2007, 120:650-655.

68. Kiviat, N. B., J. A. Paavonen, J. Brockway, C. W. Critchlow, R. C. Brunham, C. E. Stevens, W. E. Stamm, C. C. Kuo, T. DeRouen, and K. K. Holmes. Cytologic manifestations of cervical and vaginal infections. I. Epithelial and inflammatory cellular changes. JAMA 1985. 253:989-996.

69. Samoff, E., E. H. Koumans, L. E. Markowitz, M. Sternberg, M. K. Sawyer, D. Swan, J. R. Papp, C. M. Black, and E. R. Unger. Association of Chlamydia trachomatis with persistence of high-risk types of human papillomavirus in a cohort of female adolescents. Am. J. Epidemiol. 2005 162:668-675.

70. Silins, I., W. Ryd, A. Strand, G. Wadell, S. Tornberg, B. G. Hansson, X. Wang, L. Arnheim, V. Dahl, D. Bremell, K. Persson, J. Dillner, and E. Rylander. Chlamydia trachomatis infection and persistence of human papillomavirus. Int. J. Cancer 2005.116:110-115.

71. Schlott, T., H. Eiffert, W. Bohne, J. Landgrebe, E. Brunner, B. Spielbauer, and B. Knight. Chlamydia trachomatis modulates expression of tumor suppressor gene caveolin-1 and oncogene c-myc in the transformation zone of non-neoplastic cervical tissue. Gynecol. Oncol. 2005. 98:409-419.

\section{Publish in International Archives of Medicine}

International Archives of Medicine is an open access journal publishing articles encompassing all aspects of medical science and clinical practice. IAM is considered a megajournal with independent sections on all areas of medicine. IAM is a really international journal with authors and board members from all around the world. The journal is widely indexed and classified Q2 in category Medicine. 